\title{
LARVAE OF TROMBICULID MITES (ACARINA: TROMBICULIDAE) IN WILD BIRDS IN SLOVAK AND POLISH CARPATHIANS
}

\author{
I. LITERÁK ${ }^{1}$, M. HONZA ${ }^{2}$, B. PINOWSKA ${ }^{3}$, A. HAMAN ${ }^{3}$ \\ ${ }^{1}$ Department of Biology and Wildlife Diseases, Faculty of Veterinary Hygiene and Ecology, University of \\ Veterinary and Pharmaceutical Sciences, Brno, Czech Republic \\ ${ }^{2}$ Institute of Vertebrate Biology, Academy of Sciences of the Czech Republic, Brno, Czech Republic \\ ${ }^{3}$ Institute of Ecology, Polish Academy of Sciences, Dziekanów Leśny, Łomianki, Poland \\ Received May 4, 2001 \\ Accepted October 31, 2001 \\ Abstract \\ Literák I., M. Honza, B. Pinowska, A. Haman: Larvae of Trombiculid Mites (Acarina: \\ Trombiculidae) in Wild Birds in the Slovak and Polish Carpathians. Acta Vet. Brno 2001, 70: \\ 479-483. \\ The larvae of trombiculid mites were surveyed in wild birds at four localities in Slovakia and \\ one locality in Poland (all localities are situated in the Carpathian Mountains) from 1999 to 2000. \\ The total of 1354 birds of 59 species was examined between July and September. The trombiculid \\ mites were found in $169(12 \%)$ birds. The highest prevalences $(37 \%$ and $18 \%)$ were detected at \\ two forest localities in the Velká Fatra Mts., the lowest prevalence $(2 \%)$ in the High Tatras above \\ the tree line. Prevalences of more than $20 \%$ were found in Turdus philomelos $(50 \%, 5$ positive, \\ 10 examined), Prunella modularis (41 \%, 48/116), Troglodytes troglodytes (39\%, 11/28), \\ Emberiza citrinella $(29 \%, 4 / 14)$, Turdus torquatus $(29 \%, 2 / 7)$ and Erithacus rubecula (26\%, \\ 64/244). Larvae of the trombiculid mites belong to common parasites in birds in the Carpathians \\ in late summer, especially in birds which are feeding on the ground. Mite larvae were determined \\ as Neotrombicula vernalis (Willmann, 1942) in Erithacus rubecula (Krempna, Beskid Niski \\ Mts., Poland) and Prunella modularis (Blatnica, Velká Fatra Mts., Slovakia). \\ Passerines, parasites, Europe, skin, mountains, Trombiculidae
}

At various localities in Slovakia (Blatnica, Ruské, Necpaly, Tatranská Javorina) and Poland (Krempna) wild birds were examined for cutaneous trematode Collyriclum faba during summer periods from 1996 to 2000 . The foci of this trematode were recently recorded in Slovakia (Literák and Sitko 1997; Literák and Honza 2000). Cutaneous trombiculid larvae were found in some examined birds in close proximity of the cloaca.

Because there is relatively little data about trombiculid mites in wild birds in Central Europe (Daniel 1961; Haitlinger 1987), the aim of our work was to document and compare the prevalences of their larvae in individual species of wild birds in study areas.

\section{Materials and Methods}

Birds were captured in mist-nets and visually examined for cutaneous cysts of Collyriclum faba. Skin was checked on the legs, ventral part of the body, especially between the sternum and cloaca, below the wings, around the preen gland, and on the whole head. Trombiculid larvae were recorded and their occurrence was retrospectively evaluated. Only parasites of two birds were collected into $70 \%$ ethanol and determined in the laboratory.

\section{Site descriptions}

Blatnica (Martin District) - 48.56 N 18.56 E, 940 m above sea level

The trapping site lies in the Veterná Valley of the Velká Fatra Mts. near a stream lined mainly with stands of beech Fagus sylvatica and spruce Picea abies. Birds were trapped between 2 and 8 August 1999.

Ruské (Snina District) - 49.07 N 22.21 E, 600 m above sea level

An area abandoned by its former inhabitants in the vicinity of the source of the Cirocha River, Bukovské Hills. Birds were trapped in successive tree growths near the former village of Ruské. At trapping sites, areas with

Address for correspondence:

Doc. MVDr. Ivan Literák, CSc.

Department of Biology and Wildlife Disease

Faculty of Veterinary Hygiene and Ecology

Phone: + 420541562525

Fax: + 420549243020

http://www vfu.cz/acta-vet/actavet.htm 
deciduous trees of different age with a predominance of beech alternated with meadows. The birds were examined between 11 and 25 September 1999.

Necpaly (Martin District) - 48.59 N 18.58 E, 760 m above sea level

The trapping site lies near a stream in the Necpalská Valley in the Velká Fatra Mts. The most numerous around the site were beech and spruce trees. Birds were examined here from 25 July to 6 August 2000.

Tatranská Javorina (Kežmarok District) - 49.16 N 20.09 E, 1450 m above sea level

The trapping site lies in the Javorová Valley in the High Tatras just above the tree line. Birds were trapped in dwarf mountain pines Pinus mugo, and along a borderline between the dwarf pines and a mountain meadow. Birds were examined between 8 and 19 August 2000.

Krempna (Jaslo District) - 49.30 N 21.29 E, 400 m above sea level

The trapping site was on the borderline between farms and large forests in the Beskid Niski Mts. The nets were situated near a stream along the edge of a deciduous forest, and in a shrub growth between farm buildings. Birds were examined between 21 and 26 August 2000.

\section{Results}

Parasite determination

Mites were collected from two birds for correct species determination. The mites collected from Prunella modularis (Blatnica, Veterná Valley, 3 August 1999), see Plate VI, Fig. 1, and from Erithacus rubecula (Krempna, 22 August 2000) coincided with characteristics typical of the genus Neotrombicula and within the frame of intraspecific variability corresponded with Neotrombicula vernalis (Willmann 1942) of the species complex Neotrombicula autumnalis (Shaw 1790) as described by Kepka (1964ab, 1966) and Vercammen-Grandjean and Kolebinova (1985).

Intensity of infection and prevalence of trombiculid mite larvae in wild birds

The intensity of parasitic infection varied among individual birds - from individual mites to mite groups not countable by eye. In the case of more mites, clearly demarcated orange colonies with the diameter up to $1 \mathrm{~mm}$ were seen. In some cases, there were more mites around the cloaca or created a ring-shaped circle round the cloaca (Plate VI, Fig. 2).

Positive birds for trombiculid larvae were determined in 14 out of 59 examined bird species (Table 1). In six species (Emberiza citrinella, Erithacus rubecula, Prunella modularis, Troglodytes troglodytes, Turdus philomelos, and T. torquatus) the prevalences were higher than 20\%. In three species (Parus major, P. montanus a Sylvia communis) the prevalences were $10-20 \%$, and in five other species (Fringilla coelebs, Parus caeruleus, $P$. palustris, Sylvia atricapilla and Turdus merula) were under $10 \%$.

The parasites were found in all of the five Carpathian localities (Table 1). Prevalences of neotrombiculid larvae reached $37 \%$ in Blatnica in August 1999, $10 \%$ in Ruské in September $1999,18 \%$ in Necpaly between July and August 2000, 2 \% in Tatranská Javorina in August 2000, and $14 \%$ in Krempna in August 2000. The total prevalence was $12 \%$.

\section{Discussion}

The mite Neotrombicula vernalis collected from two birds (Prunella modularis in Slovakia and Erithacus rubecula in Poland) was unambiguously determined. Because findings in other birds were practically identical concerning colour and size of parasites as well as the place in immediate proximity of the cloaca, these mites were determined as trombiculid larvae.

Trombiculid larvae that infest mammals and birds can usually cause skin pruritus in affected individuals due to saliva excretion of larvae. Lytic enzymes in saliva cause the formation of tubes penetrating dermis (histiosiphon or stylostom) so that the larvae can suck macerated tissue of the host (Coignoul 1976). Heavily parasitized birds become droopy, refuse to eat, and may die from starvation and exhaustion (Philips 1998). Intensity of the larvae of neotrombiculid mite infection was in some cases, especially in Prunella modularis 
Table 1

Occurrence of larvae of trombiculid mites in wild birds from Carpathians

\begin{tabular}{|c|c|c|c|c|c|c|}
\hline Species & $\begin{array}{c}\text { Blatnica } \\
\text { August } \\
1999 \\
\end{array}$ & $\begin{array}{c}\text { Ruské } \\
\text { September } \\
1999 \\
\end{array}$ & $\begin{array}{c}\text { Necpaly } \\
\text { July-August } \\
2000\end{array}$ & $\begin{array}{c}\text { Tatranská } \\
\text { Javorina } \\
\text { August } 2000 \\
\end{array}$ & $\begin{array}{c}\text { Krempna } \\
\text { August } \\
2000\end{array}$ & Total \\
\hline Accipiter nisus & $\mathrm{Nt}$ & $0^{1} / 2^{2}\left(0^{3}\right)$ & $\mathrm{Nt}$ & $\mathrm{Nt}$ & $\mathrm{Nt}$ & $0 / 2(0)$ \\
\hline Acrocephalus palustris & $0 / 1(0)$ & $\mathrm{Nt}$ & $\mathrm{Nt}$ & $\mathrm{Nt}$ & $0 / 1(0)$ & $0 / 2(0)$ \\
\hline Alcedo atthis & $\mathrm{Nt}$ & $\mathrm{Nt}$ & $\mathrm{Nt}$ & $\mathrm{Nt}$ & $0 / 3(0)$ & $0 / 3(0)$ \\
\hline Aegithalos caudatus & $\mathrm{Nt}$ & $0 / 11(0)$ & $\mathrm{Nt}$ & $\mathrm{Nt}$ & $\mathrm{Nt}$ & $0 / 11(0)$ \\
\hline Anthus trivialis & $\mathrm{Nt}$ & $0 / 5(0)$ & $0 / 2(0)$ & $\mathrm{Nt}$ & $\mathrm{Nt}$ & $0 / 7(0)$ \\
\hline Bonasa bonasia & $\mathrm{Nt}$ & $0 / 1(0)$ & $\mathrm{Nt}$ & $0 / 1(0)$ & $\mathrm{Nt}$ & $0 / 2(0)$ \\
\hline Buteo buteo & $\mathrm{Nt}$ & $0 / 2(0)$ & $\mathrm{Nt}$ & $\mathrm{Nt}$ & $\mathrm{Nt}$ & $0 / 2(0)$ \\
\hline Carduelis carduelis & $\mathrm{Nt}$ & $0 / 2(0)$ & $\mathrm{Nt}$ & $\mathrm{Nt}$ & $\mathrm{Nt}$ & $0 / 2(0)$ \\
\hline Carduelis spinus & $0 / 1(0)$ & $\mathrm{Nt}$ & $0 / 1(0)$ & $0 / 1(0)$ & $\mathrm{Nt}$ & $0 / 3(0)$ \\
\hline Certhia familiaris & $0 / 1(0)$ & $0 / 1(0)$ & $0 / 2(0)$ & $0 / 2(0)$ & $0 / 2(0)$ & $0 / 8(0)$ \\
\hline Cinclus cinclus & $0 / 3(0)$ & $\mathrm{Nt}$ & $\mathrm{Nt}$ & $\mathrm{Nt}$ & $\mathrm{Nt}$ & $0 / 3(0)$ \\
\hline Coccothraustes coccothraustes & $\mathrm{Nt}$ & $0 / 1(0)$ & $\mathrm{Nt}$ & $\mathrm{Nt}$ & $\mathrm{Nt}$ & $0 / 1(0)$ \\
\hline Crex crex & $\mathrm{Nt}$ & $0 / 1(0)$ & $\mathrm{Nt}$ & $\mathrm{Nt}$ & $\mathrm{Nt}$ & $0 / 1(0)$ \\
\hline Delichon urbica & $\mathrm{Nt}$ & $\mathrm{Nt}$ & $\mathrm{Nt}$ & $0 / 1(0)$ & $\mathrm{Nt}$ & $0 / 1(0)$ \\
\hline Dendrocopos leucotos & $\mathrm{Nt}$ & $0 / 1(0)$ & $\mathrm{Nt}$ & $\mathrm{Nt}$ & $\mathrm{Nt}$ & $0 / 1(0)$ \\
\hline Dendrocopos major & $\mathrm{Nt}$ & $0 / 2(0)$ & $\mathrm{Nt}$ & $\mathrm{Nt}$ & $\mathrm{Nt}$ & $0 / 2(0)$ \\
\hline Dendrocopos minor & $\mathrm{Nt}$ & $0 / 1(0)$ & $\mathrm{Nt}$ & $\mathrm{Nt}$ & $\mathrm{Nt}$ & $0 / 1(0)$ \\
\hline Emberiza citrinella & $\mathrm{Nt}$ & $0 / 1(0)$ & $\mathrm{Nt}$ & $\mathrm{Nt}$ & $4 / 13(31)$ & 4/14 (29) \\
\hline Erithacus rubecula & $14 / 22(64)$ & $36 / 130(28)$ & $6 / 38(16)$ & $0 / 27(0)$ & $8 / 27(30)$ & $64 / 244(26)$ \\
\hline Ficedula hypoleuca & $\mathrm{Nt}$ & $\mathrm{Nt}$ & $\mathrm{Nt}$ & $0 / 2(0)$ & $\mathrm{Nt}$ & $0 / 2(0)$ \\
\hline Ficedula parva & $\mathrm{Nt}$ & $0 / 3(0)$ & $0 / 1(0)$ & $0 / 1(0)$ & $0 / 1(0)$ & $0 / 6(0)$ \\
\hline Fringilla coelebs & 1/6 (17) & $1 / 12(8)$ & $\mathrm{Nt}$ & $0 / 3(0)$ & $2 / 27(7)$ & $4 / 48(8)$ \\
\hline Garrulus glandarius & $\mathrm{Nt}$ & $0 / 4(0)$ & $\mathrm{Nt}$ & $\mathrm{Nt}$ & $\mathrm{Nt}$ & $0 / 4(0)$ \\
\hline Hippolais icterina & $\mathrm{Nt}$ & $0 / 1(0)$ & $\mathrm{Nt}$ & $\mathrm{Nt}$ & $0 / 3(0)$ & $0 / 4(0)$ \\
\hline Hirundo rustica & $\mathrm{Nt}$ & $\mathrm{Nt}$ & $\mathrm{Nt}$ & $\mathrm{Nt}$ & $0 / 15(0)$ & $0 / 15(0)$ \\
\hline Jynx torquilla & $\mathrm{Nt}$ & $\mathrm{Nt}$ & $\mathrm{Nt}$ & $0 / 1(0)$ & $\mathrm{Nt}$ & $0 / 1(0)$ \\
\hline Lanius collurio & $\mathrm{Nt}$ & $0 / 3(0)$ & $\mathrm{Nt}$ & $\mathrm{Nt}$ & $0 / 1(0)$ & $0 / 4(0)$ \\
\hline Locustella naevia & $\mathrm{Nt}$ & $\mathrm{Nt}$ & $\mathrm{Nt}$ & $\mathrm{Nt}$ & $0 / 1(0)$ & $0 / 1(0)$ \\
\hline Motacilla cinerea & $0 / 8(0)$ & $\mathrm{Nt}$ & $0 / 2(0)$ & $\mathrm{Nt}$ & $\mathrm{Nt}$ & $0 / 10(0)$ \\
\hline Muscicapa striata & $\mathrm{Nt}$ & $\mathrm{Nt}$ & $\mathrm{Nt}$ & $\mathrm{Nt}$ & $0 / 4(0)$ & $0 / 4(0)$ \\
\hline Nucifraga caryocatactes & $\mathrm{Nt}$ & $0 / 4(0)$ & $\mathrm{Nt}$ & $\mathrm{Nt}$ & $\mathrm{Nt}$ & $0 / 4(0)$ \\
\hline Parus ater & $0 / 1(0)$ & $0 / 2(0)$ & $\mathrm{Nt}$ & $0 / 24(0)$ & $0 / 1(0)$ & $0 / 28(0)$ \\
\hline Parus caeruleus & $0 / 3(0)$ & $2 / 45(4)$ & $\mathrm{Nt}$ & $\mathrm{Nt}$ & $0 / 5(0)$ & $2 / 53(4)$ \\
\hline Parus cristatus & $\mathrm{Nt}$ & $\mathrm{Nt}$ & $\mathrm{Nt}$ & $0 / 2(0)$ & $\mathrm{Nt}$ & $0 / 2(0)$ \\
\hline Parus major & $\mathrm{Nt}$ & 9/54 (17) & $0 / 1(0)$ & $\mathrm{Nt}$ & 2/11 (18) & $11 / 66(17)$ \\
\hline Parus montanus & $0 / 1(0)$ & $2 / 7(29)$ & $\mathrm{Nt}$ & $0 / 2(0)$ & $2 / 16(13)$ & $4 / 26(15)$ \\
\hline Parus palustris & $\mathrm{Nt}$ & $1 / 8(13)$ & $0 / 2(0)$ & $\mathrm{Nt}$ & $0 / 6(0)$ & $1 / 16(6)$ \\
\hline Phoenicurus ochruros & $\mathrm{Nt}$ & $\mathrm{Nt}$ & $0 / 1(0)$ & $0 / 3(0)$ & $0 / 1(0)$ & $0 / 5(0)$ \\
\hline Phoenicurus phoenicurus & $\mathrm{Nt}$ & $0 / 1(0)$ & $\mathrm{Nt}$ & $\mathrm{Nt}$ & $\mathrm{Nt}$ & $0 / 1(0)$ \\
\hline Phylloscopus collybita & $0 / 17(0)$ & $0 / 187(0)$ & $0 / 2(0)$ & $0 / 26(0)$ & $0 / 33(0)$ & $0 / 265(0)$ \\
\hline Phylloscopus sibilatrix & $\mathrm{Nt}$ & $\mathrm{Nt}$ & $\mathrm{Nt}$ & $\mathrm{Nt}$ & $0 / 2(0)$ & $0 / 2(0)$ \\
\hline Phylloscopus trochilus & $0 / 2(0)$ & $0 / 12(0)$ & $\mathrm{Nt}$ & $0 / 1(0)$ & $\mathrm{Nt}$ & $0 / 15(0)$ \\
\hline Picus canus & $\mathrm{Nt}$ & $0 / 2(0)$ & $\mathrm{Nt}$ & $\mathrm{Nt}$ & $\mathrm{Nt}$ & $0 / 2(0)$ \\
\hline Prunella modularis & $28 / 30(93)$ & $3 / 7(43)$ & $7 / 10(70)$ & $5 / 63(8)$ & $5 / 6(83)$ & $48 / 116(41)$ \\
\hline Pyrrhulla pyrrhulla & $0 / 3(0)$ & $0 / 4(0)$ & $0 / 2(0)$ & $0 / 3(0)$ & $0 / 8(0)$ & $0 / 20(0)$ \\
\hline Regulus ignicapillus & $\mathrm{Nt}$ & $\mathrm{Nt}$ & $\mathrm{Nt}$ & $\mathrm{Nt}$ & $0 / 1(0)$ & $0 / 1(0)$ \\
\hline Regulus regulus & $\mathrm{Nt}$ & $\mathrm{Nt}$ & $0 / 1(0)$ & $0 / 64(0)$ & $\mathrm{Nt}$ & $0 / 65(0)$ \\
\hline Saxicola rubetra & $\mathrm{Nt}$ & $\mathrm{Nt}$ & $\mathrm{Nt}$ & $0 / 1(0)$ & $\mathrm{Nt}$ & $0 / 1(0)$ \\
\hline Scolopax rusticola & $\mathrm{Nt}$ & $0 / 2(0)$ & $\mathrm{Nt}$ & $\mathrm{Nt}$ & $\mathrm{Nt}$ & $0 / 2(0)$ \\
\hline Sitta europaea & $0 / 1(0)$ & $\mathrm{Nt}$ & $\mathrm{Nt}$ & $\mathrm{Nt}$ & $0 / 1(0)$ & $0 / 2(0)$ \\
\hline Strix aluco & $\mathrm{Nt}$ & $\mathrm{Nt}$ & $0 / 1(0)$ & $\mathrm{Nt}$ & $\mathrm{Nt}$ & $0 / 1(0)$ \\
\hline Sylvia atricapilla & $1 / 25(4)$ & $2 / 53(4)$ & $1 / 20(5)$ & $0 / 15(0)$ & $5 / 34(15)$ & $9 / 147(6)$ \\
\hline Sylvia borin & $0 / 1(0)$ & $\mathrm{Nt}$ & $0 / 1(0)$ & $0 / 1(0)$ & $0 / 4(0)$ & 0/7 (0) \\
\hline Sylvia communis & $\mathrm{Nt}$ & $1 / 1(100)$ & $\mathrm{Nt}$ & $0 / 1(0)$ & $1 / 11(9)$ & $2 / 13(15)$ \\
\hline Sylvia curruca & $\mathrm{Nt}$ & $0 / 2(0)$ & $\mathrm{Nt}$ & $\mathrm{Nt}$ & $0 / 2(0)$ & $0 / 4(0)$ \\
\hline Troglodytes troglodytes & $0 / 1(0)$ & $5 / 18(28)$ & $1 / 2(50)$ & $0 / 1(0)$ & $5 / 6(83)$ & $11 / 28(39)$ \\
\hline Turdus merula & $\mathrm{Nt}$ & 2/27 (7) & $0 / 8(0)$ & $\mathrm{Nt}$ & $0 / 1(0)$ & 2/36(6) \\
\hline Turdus philomelos & $3 / 3(100)$ & $0 / 2(0)$ & $2 / 3(67)$ & $0 / 1(0)$ & $0 / 1(0)$ & $5 / 10(50)$ \\
\hline Turdus torquatus & $1 / 1(100)$ & $\mathrm{Nt}$ & $1 / 1(100)$ & $0 / 5(0)$ & $\mathrm{Nt}$ & $2 / 7(29)$ \\
\hline Total & $48 / 131(37)$ & $64 / 622(10)$ & $18 / 101(18)$ & $5 / 252(2)$ & $34 / 248(14)$ & $169 / 1354(12)$ \\
\hline
\end{tabular}

$\mathrm{Nt}$ - Not tested, ${ }^{1}$ - Positive, ${ }^{2}$ - Tested, ${ }^{3}$ - Prevalence $(\%)$, 
so heavy, that a negative influence on the health status was probable in affected individuals.

According to our results, the infestation of wild birds by trombiculid larvae is common in Slovak Carpathians from July to September. There is not much work on this topic in Central Europe. Only Daniel (1961) examined 16 species of birds in the area of eastern Slovakia (Ondava Higlands). He found in four bird species four species of trombiculid larvae: Neotrombicula autumnalis (Shaw 1792) s. 1. in Turdus ericetorum and Phoenicurus ochruros, Neotrombicula talmiensis (Schluger, 1955) in Sylvia communis, Leptotrombidium europaeum (Daniel et Brelih, 1959) and Ascoschoengastia latyshevi (Schluger, 1955) in Parus major.

$N$. autumnalis belongs to the commonly occurring mites in Slovakia (Vater, 1982); however, their distribution was studied especially in small ground mammals (recently, e.g. Kalúz et al., 1996). From the species group of Neotrombicula autumnalis, the species Neotrombicula inopinata (Oudemans, 1909), N. vernalis (Willmann 1942) and N. earis (Kepka 1964) were found in small mammals in Vihorlat Mts., Malé Karpaty Mts. and in the Záhorská Lowlands (Ko váčik 1983, 1984, 1985). The species N. vernalis and N. earis are considered to be the steppe species in the area of the Malé Karpaty Mts., inhabiting forest-steppe and steppe habitats. Our finding of $N$. vernalis in Prunella modularis in the higher part of Vel'ká Fatra Mts. indicates that the ecological valence of this species is larger than predicted.

In Poland, N. autumnalis s.l. belongs to the commonly occurring mites. However, in birds it was described for the first time in Sitta europaea in September 1982 (Haitlinger 1987).

It is obvious that affected wild birds in the Slovak and Polish Carpathians often foraged on the ground. A remarkably high prevalence of mite larvae was found in some Slovak localities, especially in Prunella modularis. We think that different prevalences in individual species of wild birds depend on various length of individual exposure in the environment with neotrombiculid larvae occurrence. All six species with prevalence higher than $20 \%$ belong to the ground feeding or near-ground feeding species. Individuals from other groups feed on the ground only occasionally and that apparently is the reason for their lower parasitic prevalence.

In the forests of the Carpathians in the Velká Fatra Mts., Bukovské Hills and Beskid Niski Mts., the mite larvae prevalence was $10-37 \%$. A remarkably lower $2 \%$ prevalence was noticed in wild birds in the High Tatras. The growth of dwarf pines above the tree line in Javorová Valley, the site of bird examination in the High Tatras is probably less convenient for larvae of trombiculid mites than the Carpathian forests, nevertheless the occurrence of larvae of trombiculid mites is possible even in this environment at $1450 \mathrm{~m}$ above sea level.

In affected birds, larvae of trombiculid mites were exclusively in close proximity to the cloaca. Mites N. autumnalis were observed in Turdus merula in the Netherlands in the same body area (Bronsvijk 1977).

\section{Larvy sametek (Acarina: Trombiculidae) u volně žijících ptáků ve slovenských a polských Karpatech}

V letech 1999-2000 byli na čtyřech lokalitách Slovenska a jedné lokalitě v Polsku (všechny lokality se nacházejí v Karpatech) vyšetřováni volně žijící ptáci na přítomnost larev roztočů z čeledi Trombiculidae. Během měsíců červenec až září bylo vyšetřeno 1354 ptáků 59 druhů. Napadeno bylo celkem 169 (12\%) ptáků na všech pěti lokalitách. Nejvyšší prevalence (37 \% a $18 \%$ ) byly na 2 lesních lokalitách ve Velké Fatře, nejnižší (2\%) na lokalitě ve Vysokých Tatrách, která se nacházela nad horní hranicí lesa. Prevalence vyšší než $20 \%$ byla u Turdus philomelos (50 \%, 5 pozitivních, 10 vyšetřených), Prunella modularis (41\%, 48/116), Troglodytes troglodytes (39\%, 11/28), Emberiza citrinella (29 $\%, 4 / 14)$, Turdus torquatus $(29 \%, 2 / 7)$ a Erithacus rubecula $(26 \%, 64 / 244)$. Larvy roztoču 
čeledi Trombiculidae jsou v Karpatech během pozdně letního období častými parazity ptáků, kteří se při sběru potravy pohybují na zemi. Larvy roztočů z Erithacus rubecula (Krempna, Beskid Niski, Polsko) a z Prunela modularis (Blatnica, Velká Fatra, Slovensko) byly determinovány jako Neotrombicula vernalis (Willmann, 1942).

\section{Acknowledgement}

This study was aided by the grants of the Czech-Slovak (No. 82070) and the Czech-Polish (No. 4157) intergovernment support of scientific research for the years 2000 and 2001 and the grant of the Ministry of Education, Youth and Sports of the Czech Republic No. 161700 001. We thank to Dr. František Dusbábek for trombiculid larvae determination as well as for his critical comment on the text.

\section{References}

BRONSVIJK, J.E.M.H. van 1977: Chigger infestation of a nineteenth century fortress near Utrecht, The Netherlands (Acari: Trombiculidae). Int. J. Acarology 3: 27-36

COIGNOUL, F. 1976: Infestation par les Trombididae chez les carnivores domestiques. Ann. Med. Veter. 120: 549-550

DANIEL, M. 1961: The bionomics and developmental cycle of some chiggers (Acariformes, Trombiculidae) in the Slovak Carpathians. Čs. Parasitol. 7: 31-118

HAITLINGER, R. 1987: Dermanyssus alaudae (Schrank, 1781) i inne roztocze (Acari: Dermanyssidae, Macronyssidae, Hirstionyssidae, Trombiculidae, Erythraeidae) zebrane z ptaków w Polsce. Wiad. Parazyt. 33: 233-245

KALÚZ, S., MÁJSKY, J., HRBATY, J. 1996: Chiggers (Acarina: Trombiculidae) in forest and wind-break of the Danubian plain. Biológia (Bratislava) 51: 135-141

KEPKA, O. 1964a: Zur Taxonomie der Formen von Neotrombicula (N.) autumnalis (Shaw 1790), (Acari, Trombiculidae). Zeitschr. Zool. Syst. Evolutionsforschung 2: 123-173

KEPKA, O. 1964b: Die Trombiculinae (Acari, Trombiculidae) in Österreich. Zeitschr. Parasitenkde 23: 548-642

KEPKA, O. 1966: Trombiculidae (Acari) aus Türkei. II. Zeitschr. Parasitenkde 27: 43-63

KOVÁČIK, J. 1983: Roztoče čelade Trombiculidae (Acarina) drobných zemných cicavcov Vihorlatu. Zbor. Vých.-slov. Múz. Košice, Prír. vedy 23: 183 - 190

KOVÁČIK, J. 1984: Trombikuly (Acarina, Trombiculidae) Záhorskej nížiny a Malých Karpát. Biológia (Bratislava) 39: 215-222

KOVÁČIK, J. 1985: Poznámky k ekológii larev trombikúl (Acarina: Trombiculidae) Záhorskej nížiny a Malých Karpát. Biológia (Bratislava) 40: 613-620

LITERÁK, I., HONZA M. 2000: Trematode Collyriclum faba in small passerines in the Velká Fatra Mountains. Helminthologia 37: 185

LITERÁK, I., SITKO J.: Prevalence of the trematode Collyriclum faba in robins (Erithacus rubecula) in Slovakia. Veter. Rec. 141: 273-274

PHILIPS, J.R.. 1998: Mites (Ectoparasites, Poultry). In: Aiello S. (ed.).: The Merck Veterinary Manual (Eighth Edition). MERCK and CO., INC., Whitehouse Station, N. J., USA, p. 1958-1960

VATER, G. 1982: Zur geographischen Verbreitung der Erntemilbe Neotrombicula autumnalis (Acari: Trombiculidae. Zool. Jb. Syst. 109: 329-356

VERCAMMEN- GRANDJEAN, P. H., KOLEBINOVA, M. 1985: Revision of Neotrombicula complex (Acarina: Trombiculidae). Acta Zool. Bulgarica 29: 65-78 
Plate V

Literák I. et al.: Larvae... pp. 479-483.
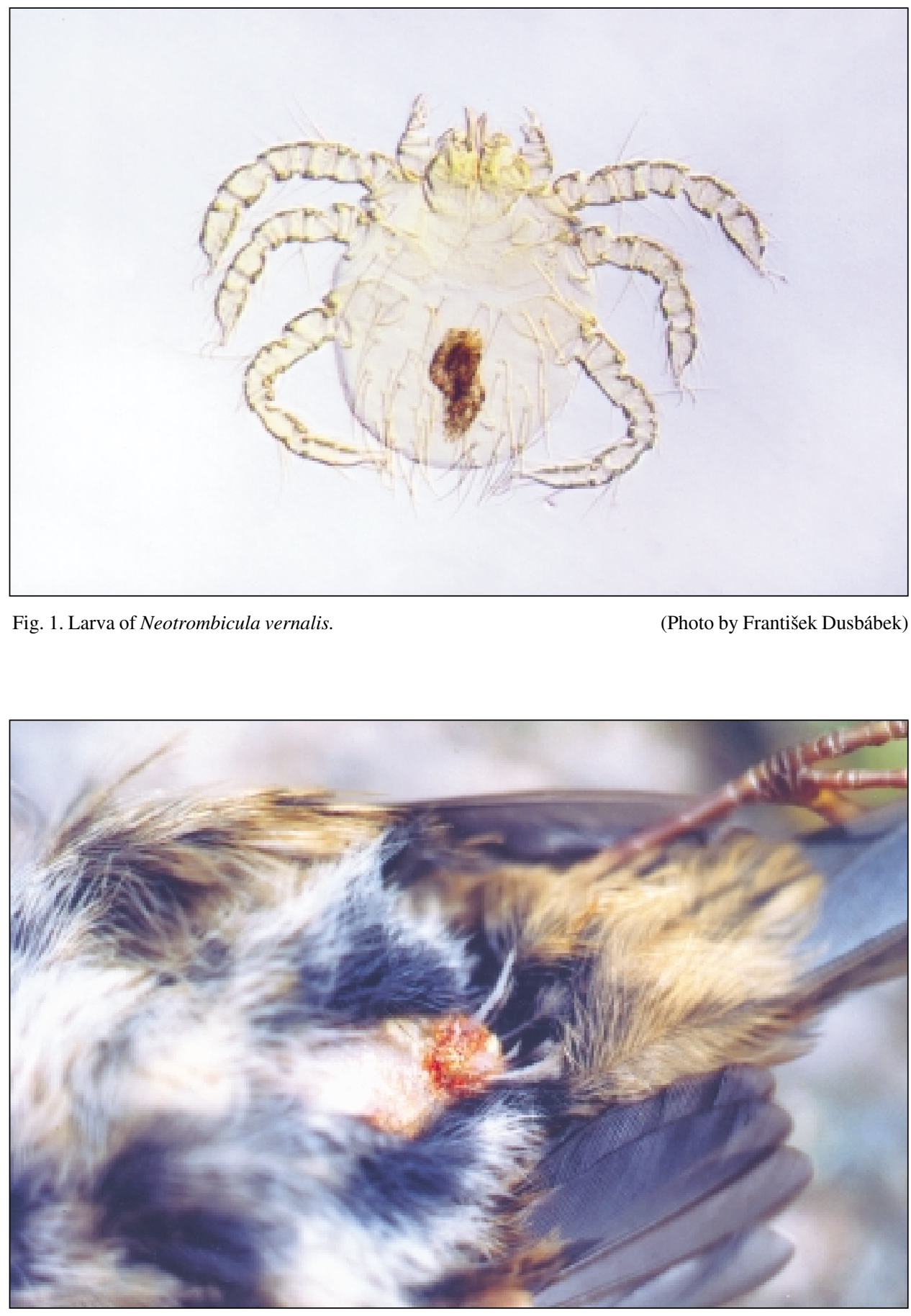

Fig. 2. Prunella modularis with larvae of Neotrombicula vernalis around its cloaca. $\quad$ (Photo by Marcel Honza) 